\title{
Modulators with Convergent Cellular Actions Elicit Distinct Circuit Outputs
}

\author{
Andrew M. Swensen and Eve Marder \\ Volen Center and Biology Department, Brandeis University, Waltham, Massachusetts 02454
}

Six neuromodulators [proctolin, Cancer borealis tachykininrelated peptide la, crustacean cardioactive peptide (CCAP), red pigment-concentrating hormone, TNRNFLRFamide, and pilocarpine] converge onto the same voltage-dependent inward current in stomatogastric ganglion (STG) neurons of the crab $C$. borealis. We show here that each of these modulators acts on a distinct subset of pyloric network neurons in the STG. To ask whether the differences in cell targets could account for their differential effects on the pyloric rhythm, we systematically compared the motor patterns produced by proctolin and CCAP. The motor patterns produced in proctolin and CCAP differed quantitatively in a number of ways. Proctolin and CCAP both act on the lateral pyloric neuron and the inferior cardiac neuron.
Proctolin additionally acts on the pyloric dilator (PD) neurons, the pyloric (PY) neurons, and the ventricular dilator neuron. Using the dynamic clamp, we introduced an artificial peptideelicited current into the PD and PY neurons, in the presence of CCAP, and converted the CCAP rhythm into a rhythm that was statistically similar to that seen in proctolin. This suggests that the differences in the network effects of these two modulators can primarily be attributed to the known differential distributions of their receptors onto distinct subsets of neurons, despite the fact that they activate the same current.

Key words: stomatogastric ganglion; crab; Cancer borealis; proctolin; CCAP; RPCH; CabTRP; FLRFamide-related peptides
All nervous systems use a large number of different signaling molecules as neurotransmitters and neuromodulators. In principle, voltage-dependent and ligand-gated channels, chemical synapses, and electrical synapses are all subject to neuromodulation, resulting in changes in circuit activity and output (Marder and Calabrese, 1996). The large number of potential sites for neuromodulation within a circuit often makes it difficult to understand exactly how modulation of one or more currents in one or more neurons within a circuit results in altered circuit activity. Understanding how modulation at the cellular level translates into altered circuit output can be profitably studied in relatively small nervous systems, in which the number of neurons involved allows the investigator to identify the neurons that are direct targets of modulation (Marder and Eisen, 1984b; Flamm and HarrisWarrick, 1986; Hooper and Marder, 1987). The stomatogastric ganglion (STG) of crabs contains only 26-27 neurons (Kilman and Marder, 1996) but is modulated by 15-20 different substances (Marder, 1987; Christie et al., 1995; Marder et al., 1995). This raises a series of issues about how multiple neuromodulators can act on the same circuits to produce a variety of behaviors.

Recently we found that six modulators [proctolin, Cancer borealis tachykinin-related peptide Ia (CabTRP), TNRNFLRFamide, crustacean cardioactive peptide (CCAP), red pigmentconcentrating hormone (RPCH), and the muscarinic agonist pilocarpine] that elicit distinct effects on the rhythmic output of the STG (Marder and Hooper, 1985; Marder and Weimann, 1992) converge onto the same voltage-dependent current (Swensen and Marder, 2000). This is in contrast to the amines

Received Feb. 9, 2001; revised March 15, 2001; accepted March 16, 2001.

This research was supported by National Institutes of Health Grant NS17813 and the W. M. Keck Foundation.

Correspondence should be addressed to Dr. Andrew M. Swensen, Department of Neurobiology, Harvard Medical School, 220 Longwood Avenue, Boston, MA 02115. E-mail: andrew_swensen@hms.harvard.edu.

Copyright (C) 2001 Society for Neuroscience 0270-6474/01/214050-09\$15.00/0 serotonin and dopamine that modulate a variety of different currents in STG neurons (Kiehn and Harris-Warrick, 1992a,b; Harris-Warrick et al., 1995a,b, 1998; Zhang and Harris-Warrick, 1995; Zhang et al., 1995; Kloppenburg et al., 1999).

How can a network produce divergent outputs in response to multiple substances that converge onto the same current? To answer this question, we first determined which neurons of the pyloric network of the STG responded to each of the convergent modulators and found that each of the convergent modulators acts on a different subset of neurons. This suggests that the differential distribution of receptors onto distinct subsets of target neurons may be responsible for the divergent effects of these modulators on network activity. To test this hypothesis, we used the dynamic clamp (Sharp et al., 1993a,b) to introduce an artificial peptide current into specific neurons, to attempt to convert the motor patterns from those characteristically produced by one set of neuronal targets to those produced by another. Specifically, we found that by introducing an artificial peptide-activated current into two cells that do not respond to CCAP but do respond to proctolin we could convert the CCAP rhythm into a proctolin-like rhythm. This would suggest that major differences in circuit output can result from modulators that act on the same current if they act on different subsets of circuit neurons.

\section{MATERIALS AND METHODS}

Animals. C. borealis were obtained from Commercial Lobster (Boston, MA) and maintained in artificial seawater until used.

Modulators. Proctolin (Sigma, St. Louis, MO), CabTRP Ia (gift from A. E. Christie and M. P. Nusbaum), CCAP (Bachem, Torrance, CA), $\mathrm{RPCH}$ and TNRNFLRFamide (American Peptide Company, Sunnyvale, CA), and pilocarpine (Sigma) were dissolved in saline and either pressure applied using a Picospritzer (5-15 psi; 50-1000 msec) with 100-500 $\mu \mathrm{M}$ (proctolin, CabTRP, CCAP, TNRNFLRFamide, and $\mathrm{RPCH}$ ) or $10-50 \mathrm{~mm}$ (pilocarpine) in the pressure pipette or bath applied at the concentrations indicated in the text and figure legends. 
Solutions. C. borealis physiological saline was composed of (in mM): $\mathrm{NaCl}, 440 ; \mathrm{KCl}, 11 ; \mathrm{CaCl}_{2}, 13 ; \mathrm{MgCl}_{2}, 26$; Trizma base, 11; and maleic acid, 5, pH 7.4-7.5.

Recordings. The stomatogastric nervous systems were dissected out of the animals and pinned out in dishes containing Sylgard (Dow Corning, Midland, MI). During the experiments, the nervous systems were continuously superfused with chilled $\left(11-14^{\circ} \mathrm{C}\right)$ physiological saline. Extracellular recordings from nerves were made using stainless steel pin electrodes. Intracellular recordings were made using the Axoclamp 2A and $2 \mathrm{~B}$ amplifiers (Axon Instruments, Foster City, CA) in either twoelectrode current clamp, single-electrode current clamp, or two-electrode voltage clamp (TEVC). Microelectrodes used for intracellular recordings and injections contained $0.6 \mathrm{M} \mathrm{K}_{2} \mathrm{SO}_{4}$ and $20 \mathrm{mM} \mathrm{KCl}$, and electrode resistances ranged from 20 to $40 \mathrm{M} \Omega$. Data were collected and analyzed using pCLAMP software (Axon Instruments).

For the experiments performed to identify the cell targets of the various modulators and for the dose-response curves, neurons were pharmacologically isolated using $10 \mu \mathrm{M}$ picrotoxin (PTX; Sigma) to block the inhibitory glutamatergic synapses in the STG (Bidaut, 1980; Marder and Eisen, 1984a), $0.1 \mu \mathrm{M}$ tetrodotoxin (TTX; Alomone Labs, Jerusalem, Israel) to block action potential generation, and, in some cases, $10 \mathrm{~mm}$ tetraethylammonium chloride (TEA; Sigma) to block some of the $\mathrm{K}^{+}$currents. Photoinactivation was used to eliminate electrically coupled neurons (Miller and Selverston, 1979). For photoinactivation, cells were filled for 45 min with Lucifer yellow (10\%) in an electrode backfilled with $1 \mathrm{M} \mathrm{LiCl}$ ( -4 to $-8 \mathrm{nA}$ pulses). Cells sat for an additional 30-60 min before irradiation to allow the Lucifer yellow to diffuse to the outer processes.

For the experiments performed to compare the network effects of CCAP and proctolin, the STG was isolated from anterior modulatory inputs by blocking the stomatogastric nerve with a well containing sucrose $(750 \mathrm{~mm})$. Data analyses of the phase relationships and cell activity measurements were done using DataMaster, version 2.0, by William Miller. Phase relationships were calculated by dividing the time of burst onset (or offset) by the cycle period. The onset of the pyloric dilator (PD) neuron was defined as time 0 for each cycle.

Dynamic clamp. Artificial currents were introduced into neurons using a version of the dynamic clamp (Sharp et al., 1993a,b) developed by Farzan Nadim, Yair Manor, and William Miller with LabView/CVI software (National Instruments, Austin, TX). The artificial currents were described by the equation: $I=g^{*} m^{*}\left(\mathrm{~V}-E_{r}\right)$, where $m=1 /(1+$ $\left.\exp \left(\left(\mathrm{V}-\mathrm{V}_{\mathrm{m}}\right) / K_{\mathrm{m}}\right)\right), E_{r}$ is the reversal potential, $\mathrm{V}_{\mathrm{m}}$ is the half-maximal activation, and $K_{\mathrm{m}}$ is the slope of the logistic function at $\mathrm{V}_{\mathrm{m}}$. For the artificial current in the PD neuron, $E_{r}=-22 \mathrm{mV}, \mathrm{V}_{\mathrm{m}}=-21 \mathrm{mV}$, and $K_{\mathrm{m}}$ $=-8 \mathrm{mV}$. For the pyloric (PY) neuron, these values were $E_{r}=9 \mathrm{mV}, \mathrm{V}_{\mathrm{m}}$ $=-18 \mathrm{mV}$, and $K_{\mathrm{m}}=-10 \mathrm{mV}$.

Current-voltage curves. To obtain current-voltage curves, cells were voltage clamped and typically ramped from -90 to $0 \mathrm{mV}$ at $75 \mathrm{mV} / \mathrm{sec}$ (1.2 sec total). The currents elicited under control conditions were then subtracted from those obtained in the presence of the pressure-applied modulator. This difference current was plotted versus voltage to yield the current-voltage curves (Swensen and Marder, 2000).

Statistics. The SigmaPlot and SigmaStat software packages (Jandel Scientific, San Rafael, CA) were used for statistical analyses.

\section{RESULTS}

We demonstrated previously that six modulators (proctolin, CabTRP, CCAP, RPCH, TNRNFLRFamide, and pilocarpine) converge onto the same voltage-dependent current (Swensen and Marder, 2000). This current is an inward nonspecific cation current that shows strong outward rectification (Golowasch and Marder, 1992). The peak inward current is elicited at voltages ranging from -40 to $-20 \mathrm{mV}$ depending on the cell type (Swensen and Marder, 2000). We showed that although the lateral pyloric (LP) neuron responded to all six modulators, the ventricular dilator (VD) neuron responded to only a subset of the modulators (Swensen and Marder, 2000). To account for the effects of these neuromodulators on the entire network, it is necessary to determine which cell types respond to each substance. Therefore, we assayed the remaining pyloric network neurons to determine which modulators act on each cell type.

\section{The PD neurons respond to proctolin, CabTRP, and pilocarpine}

There are two PD neurons in each STG. Figure $1 A$ shows an example of the current-voltage curves for proctolin, CabTRP, and pilocarpine in an isolated PD neuron. Note the similarity in the curves and that, for each modulator, the voltage at which the peak inward current was elicited $\left(\mathrm{V}_{\text {peak }}\right)$ was approximately -35 $\mathrm{mV}$. The PD neurons responded to proctolin $(n=7)$, CabTRP $(n=8)$, and pilocarpine $(n=7)$ but not to TNRNFLRFamide $(n=4)$, CCAP $(n=5)$, or RPCH $(n=3)$. The mean $\mathrm{V}_{\text {peak }}$ values for proctolin, CabTRP, and pilocarpine were statistically indistinguishable (one-way ANOVA, $p=0.162$ ). The mean $\mathrm{V}_{\text {peak }}$ value for all PD neurons was $-30 \pm 1 \mathrm{mV}(n=8)$.

A

PD neuron
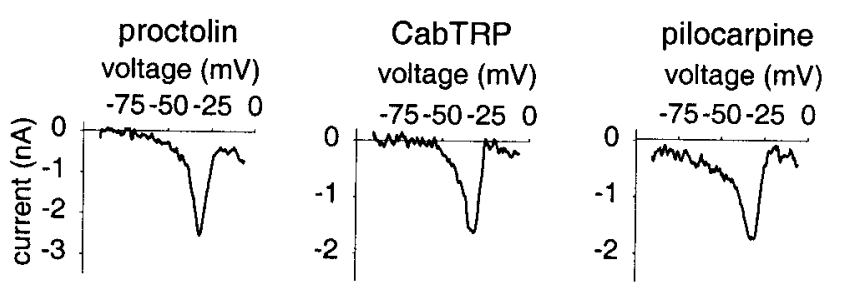

B
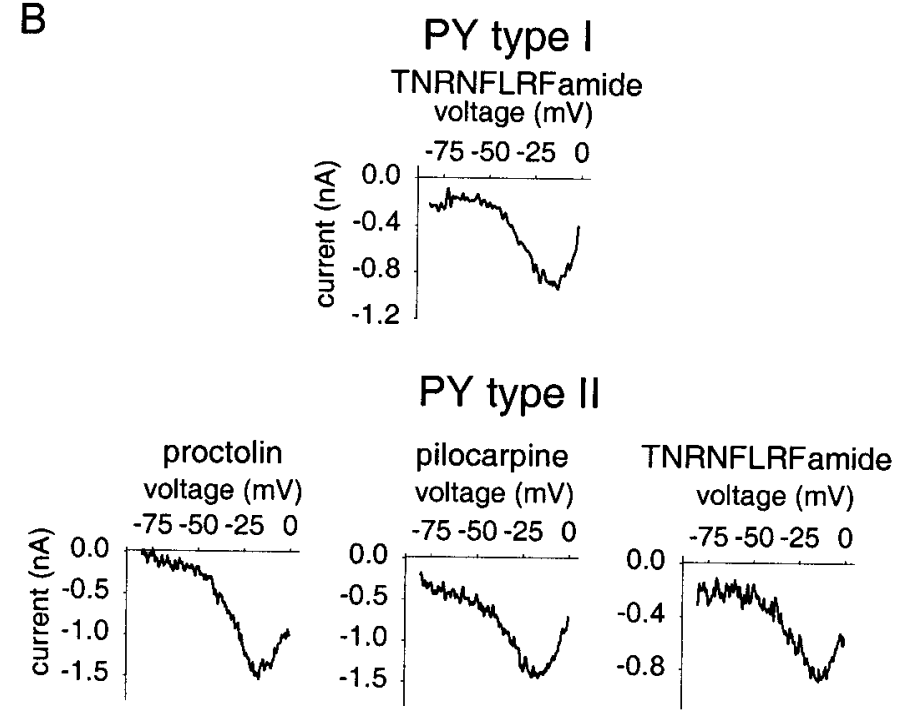

Figure 1. Modulators acting on the PD and PY neurons. A, Convergence of proctolin, CabTRP, and pilocarpine onto the PD neuron. All three modulators yield similar current-voltage curves with $V_{\text {peak }}$ values of approximately $-35 \mathrm{mV}$. Recordings were made from the same PD neuron. The PD neuron was isolated from the electrically coupled $A B$ and LPG neurons by photoinactivation. $B$, Two of the response types exhibited by PY neurons. The responses of the PY neuron fell into three categories: those that responded to only TNRNFLRFamide (type I; top), those that responded to TNRNFLRFamide, proctolin, and pilocarpine (type II; bottom), and those that responded to TNRNFLRFamide, proctolin, pilocarpine, and CabTRP (type III; data not shown). Note that all three modulators converging onto the type-II neurons yield similar current-voltage curves with $\mathrm{V}_{\text {peak }}$ values at approximately $-20 \mathrm{mV}$. Recordings were all made in TEVC. Modulators were pressure applied for 100 msec at $500 \mu \mathrm{M}$ (proctolin, CabTRP, or TNRNFLRFamide) or $50 \mathrm{~mm}$ (pilocarpine). The bath contained $10 \mu \mathrm{M}$ PTX to block the inhibitory glutamatergic synapses, $0.1 \mu \mathrm{M}$ TTX to block action potential generation, and $10 \mathrm{~mm}$ TEA to block some of the $\mathrm{K}^{+}$currents. 


\section{PY neurons fall into three categories}

In the lobster Panulirus interruptus, there are eight PY neurons that have been divided into two classes on the basis of their firing patterns and synaptic connections (Hartline et al., 1987). In the crab C. borealis, there are approximately five PY neurons (Kilman and Marder, 1996), which are also likely to be heterogeneous in terms of synaptic connectivity. Figure $1 B$ shows the currentvoltage curves for two PY neurons that responded to different subsets of the modulators. The PY neurons responding to only TNRNFLRFamide (4 of 14) were classified as type-I PY neurons. The other PY neurons responded either to TNRNFLRFamide, proctolin, and pilocarpine (type II; 6 of 14) or to TNRNFLRFamide, proctolin, pilocarpine, and CabTRP (type III; 4 of 14). None of the PY neurons tested responded to either CCAP $(n=14)$ or RPCH $(n=14)$. In three of four experiments in which we recorded from two PY neurons in the same preparation, we found that the PY neurons fell into different categories on the basis of their modulator responses. This suggests that these different PY neuron subtypes are expressed in each individual animal and are not simply a result of animal-to-animal variability. The mean $\mathrm{V}_{\text {peak }}$ values for type-I $(-18 \pm 6 \mathrm{mV} ; n=3)$, type-II $(-21 \pm 7 \mathrm{mV} ; n=5)$, and type-III $(-19 \pm 6 \mathrm{mV} ; n=4) \mathrm{PY}$ neurons were statistically indistinguishable (one-way ANOVA, $p=0.777)$. In addition, the pooled $\mathrm{V}_{\text {peak }}$ values for each individual modulator (TNRNFLRFamide, proctolin, pilocarpine, and CabTRP) across all PY neurons were not statistically different (one-way ANOVA, $p=0.587$ ).

\section{The inferior cardiac neuron responds to five of the six modulators}

There is one inferior cardiac (IC) neuron in each STG. The IC neuron responded to proctolin $(n=7)$, CabTRP $(n=7)$, CCAP $(n=5)$, TNRNFLRFamide $(n=7)$, and pilocarpine $(n=5)$ but not to $\mathrm{RPCH}(n=4)$. The $\mathrm{V}_{\text {peak }}$ measurements for the different modulators acting on the IC neuron were not statistically different (one-way ANOVA, $p=0.617$ ). The mean $\mathrm{V}_{\text {peak }}$ value for all IC neurons was $-29 \pm 5 \mathrm{mV}(n=7)$.

\section{The lateral posterior gastric neurons}

There are two lateral posterior gastric (LPG) neurons in each STG. All isolated LPG neurons responded to CabTRP $(n=7)$ but not to proctolin $(n=7)$, CCAP $(n=3)$, TNRNFLRFamide $(n=3)$, or RPCH $(n=3)$. Two of five LPG neurons responded to pilocarpine as well. The $\mathrm{V}_{\text {peak }}$ value for CabTRP in the LPG neurons was $-18 \pm 5 \mathrm{mV}(n=5)$.

\section{The anterior burster neuron}

There is one anterior burster (AB) neuron in each STG. The AB neuron is electrically coupled to the PD neurons and often has a very small soma with a narrow neck, partially isolating the soma from its major neurite and its electrically coupled partners. In voltage-clamped isolated AB neurons, we were not able to see any modulator-elicited currents in response to voltage ramps. In current-clamp recordings of isolated $\mathrm{AB}$ neuron activity, however, the modulators increased the frequency and/or enhanced the amplitude of the membrane potential oscillations of the AB neuron (proctolin, $n=5$; CabTRP, $n=3$; CCAP, $n=3$; pilocarpine, $n=2$; TNRNFLRFamide, $n=2$; and RPCH, $n=2$; data not shown).

\section{Summary of the cellular targets for each modulator}

Figure 2 summarizes the cell targets of each modulator, and Table 1 reports the measured $\mathrm{V}_{\text {peak }}$ values of the modulator
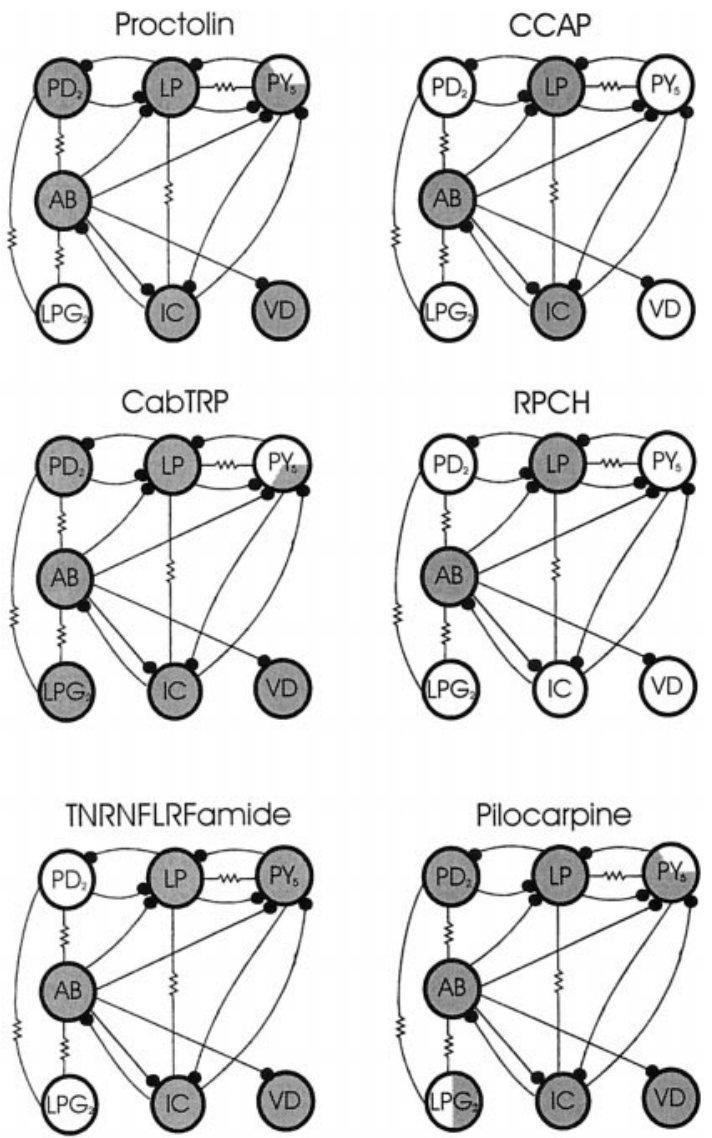

Figure 2. Pyloric circuits summarizing the target neurons (shaded) for each of the convergent modulators. Each modulator targets a different subset of cells. Neurons that exhibited multiple responses are shaded according to the percentage of the cells that did respond to a given modulator.

responses in each cell type. In Figure 2, neurons that displayed multiple response types are shaded according to the subpopulation of those neurons that showed responses.

Figure 2 shows that each of the modulators acted on a different subset of the neurons in the pyloric rhythm. On one end of the spectrum, CabTRP activated all cell types, whereas at the other end of the spectrum, RPCH had only two cell targets. To determine experimentally whether the differences in cell targets can account for differences in the motor patterns evoked by the different modulators, we wanted to select a pair of substances that differed in cell targets sufficiently to be interesting (more than one cell different) but were close enough so that we could later apply artificial peptide currents with the dynamic clamp. Therefore, we chose to compare the actions of proctolin and CCAP. The logic of the remainder of this paper is first to compare quantitatively the motor patterns evoked by proctolin and CCAP and then to determine whether we can convert a CCAP pattern to a proctolin pattern by application of the modulator current, using the dynamic clamp, to those cells that do not respond to CCAP but do respond to proctolin.

\section{Proctolin and CCAP elicit distinct effects at the network level}

The physiological actions of bath-applied proctolin and CCAP have been reported previously (Hooper and Marder, 1984; Marder et al., 1986; Nusbaum and Marder, 1989a,b; Weimann et 


\begin{tabular}{|c|c|c|c|c|c|c|c|c|c|}
\hline & \multirow[t]{2}{*}{ LP } & \multirow[t]{2}{*}{ VD } & \multirow[t]{2}{*}{ IC } & \multicolumn{3}{|c|}{ PY } & \multirow[t]{2}{*}{$\mathrm{PD}$} & \multirow[t]{2}{*}{ LPG } & \multirow[t]{2}{*}{$\mathrm{AB}$} \\
\hline & & & & I & II & III & & & \\
\hline Proctolin & Yes & Yes & Yes & $\mathrm{N}$ & $\mathrm{Y}$ & $\mathrm{Y}^{a}$ & Yes & No & Yes \\
\hline CabTRP & Yes & Yes & Yes & $\mathrm{N}$ & $\mathrm{N}$ & $\mathrm{Y}$ & Yes & Yes & Yes \\
\hline TNRN & Yes & Yes & Yes & $\mathrm{Y}$ & $\mathrm{Y}$ & $\mathrm{Y}$ & No & No & Yes \\
\hline CCAP & Yes & No & Yes & $\mathrm{N}$ & $\mathrm{N}$ & $\mathrm{N}$ & No & No & Yes \\
\hline $\mathrm{RPCH}$ & Yes & No & No & $\mathrm{N}$ & $\mathrm{N}$ & $\mathrm{N}$ & No & No & Yes \\
\hline Pilocarpine & Yes & Yes & Yes & $\mathrm{N}$ & $\mathrm{Y}$ & $\mathrm{Y}$ & Yes & Yes/no & Yes \\
\hline $\begin{array}{l}V_{\text {peak }} \\
(\mathrm{mV})\end{array}$ & $\begin{array}{l}-38 \pm 5 \\
n=35\end{array}$ & $\begin{array}{l}-20 \pm 3 \\
n=13\end{array}$ & $\begin{array}{l}-29 \pm 5 \\
n=7\end{array}$ & & $\begin{array}{l}-20 \pm 6 \\
n=12\end{array}$ & & $\begin{array}{l}-30 \pm 1 \\
n=8\end{array}$ & $\begin{array}{l}-18 \pm 5 \\
n=5\end{array}$ & $\mathrm{~N} / \mathrm{A}^{b}$ \\
\hline
\end{tabular}

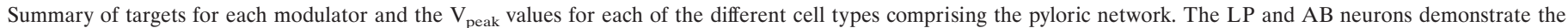

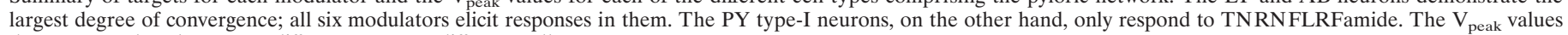
demonstrate that there were differences across different cell types.

${ }^{a} \mathrm{~N}, \mathrm{No} ; \mathrm{Y}$, yes.

${ }^{b} \mathrm{~N} / \mathrm{A}$, Not applicable.
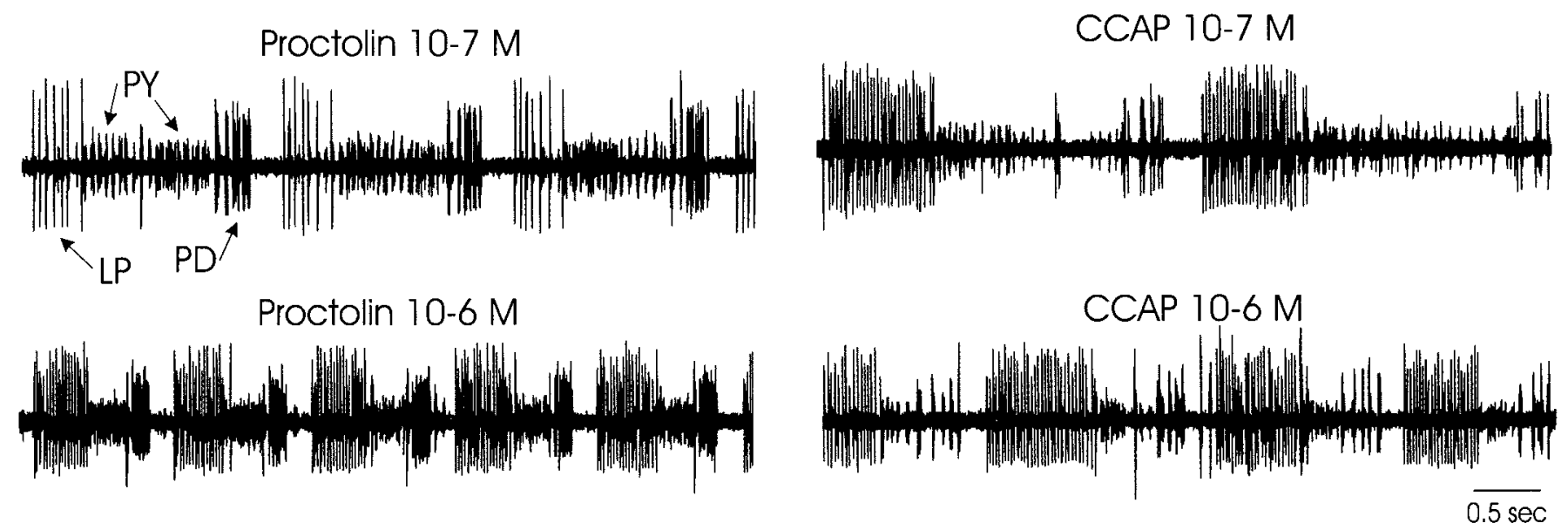

Figure 3. Proctolin- and CCAP-elicited pyloric rhythms at two different concentrations $\left(10^{-6}\right.$ and $\left.10^{-7} \mathrm{M}\right)$. Extracellular recordings are from STG motor nerves. These recordings show the activity of the pyloric neurons as labeled. Both sets of recordings are from the same preparation.

al., 1997). However, in the previous work proctolin and CCAP were studied separately, and each was compared with control saline, and there were no direct quantitative comparisons of the motor patterns evoked by these modulators. Figure 3 shows an example of proctolin and CCAP (at two concentrations) applied to the same preparation. Previous work had shown that both modulators strongly excited the LP neuron but that CCAP has a more potent action on the LP neuron at a given concentration (Hooper and Marder, 1984; Marder et al., 1986; Nusbaum and Marder, 1989a,b; Weimann et al., 1997). This can be seen in Figure 3, where the LP neuron is more strongly activated in CCAP than in proctolin at a given concentration. In $5 \times 10^{-7} \mathrm{M}$ CCAP, the LP neuron fired at a higher spike frequency $(p<$ 0.041 , paired $t$ test) and for a longer duration ( $p<0.001$, paired $t$ test) than in $10^{-6} \mathrm{M}$ proctolin $(n=8$ experiments). We wanted to ask whether there were significant differences in the pyloric rhythm in the two peptides because of effects on other target neurons, independent of differences in the activation of the LP neuron. Therefore we used LP neuron activity to normalize for potency differences between proctolin and CCAP and studied the rhythms at concentrations of the two peptides that produced equivalent spike frequency in the LP neuron.

Figure 4 shows the dose-response curves for proctolin- and CCAP-evoked currents in the LP neuron. On the basis of the best fits, at concentrations of $10^{-6} \mathrm{M}$, proctolin was at $83 \%$ of its maximal current, and CCAP was at $94 \%$ of its maximal current. To compensate for the difference in potency, as calculated from the inward currents measured in the peptides, we started by comparing the effects of $10^{-6} \mathrm{M}$ proctolin with a CCAP concentration of $3 \times 10^{-7} \mathrm{M}$. At these concentrations $\left(10^{-6} \mathrm{M}\right.$ proctolin and $3 \times 10^{-7} \mathrm{M}$ CCAP) the spike frequencies of the LP neuron in the intact network were approximately equivalent but still varied slightly depending on the preparation. To compensate for this, in each individual experiment we adjusted the CCAP concentration until the LP neuron fired at the same frequency in CCAP as in $10^{-6} \mathrm{M}$ proctolin. The CCAP concentrations for the six experiments were the following: $1.5 \times 10^{-7}, 2.0 \times 10^{-7}$, $3.0 \times 10^{-7}, 3.5 \times 10^{-7}, 5.0 \times 10^{-7}$, and $5.0 \times 10^{-7} \mathrm{M}$.

\section{Using the dynamic clamp to mimic peptide actions}

The artificial peptide currents that we used were derived from currents measured in a PD and a PY neuron. Figure $5 A$ shows the artificial peptide currents we used for the PD and PY neurons along with the actual current-voltage curves from which they were fit. Examples of the artificial currents applied to a PD neuron and a PY neuron are shown in Figure $5 B$. The left panels show control recordings for a PD and a PY neuron, and the right panels show recordings from these two cells with the addition of 


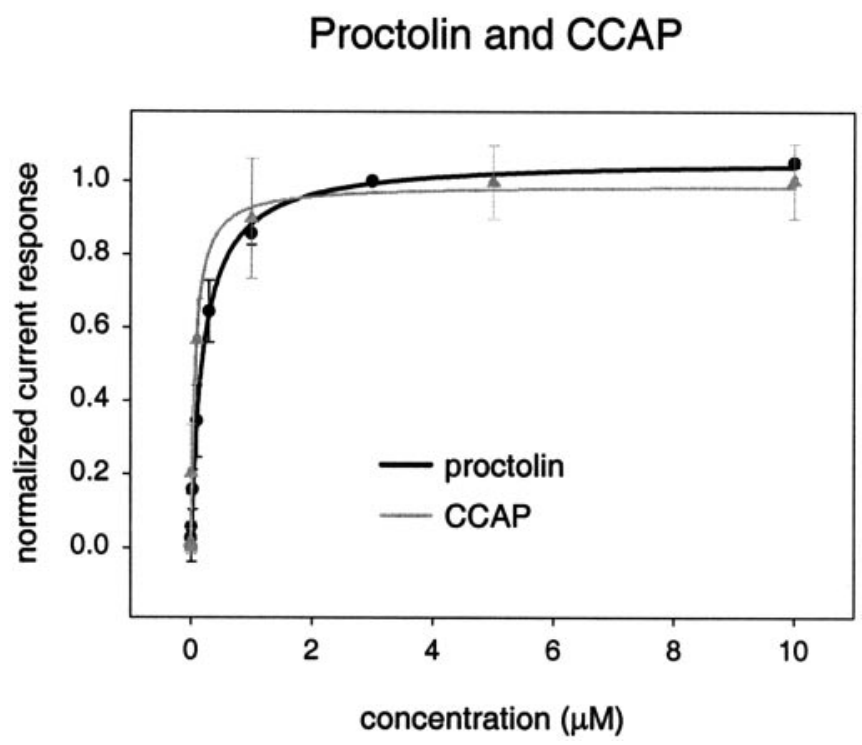

Figure 4. Dose-response curves for proctolin and CCAP in the LP neuron. The proctolin dose-response curve is adapted from Swensen and Marder (2000). For proctolin, $90 \%$ of the maximal current was reached at $1.8 \times 10^{-6} \mathrm{M}$, and for CCAP, $90 \%$ maximal was reached at $6 \times 10^{-7} \mathrm{M}$. Plotted points represent the normalized peak inward current elicited $( \pm \mathrm{SE})$ in the LP neuron while voltage clamped to $-40 \mathrm{mV}$. The bath contained $10 \mu \mathrm{M}$ PTX and $0.1 \mu \mathrm{M}$ TTX. Points were fit to the equation: $y=\left(I_{\max }\right) x /\left(K_{\mathrm{d}}+x\right)$, where $x$ is the concentration of the applied peptide, $I_{\max }$ is the normalized maximal current, and $K_{\mathrm{d}}$ is the dissociation constant. For proctolin, $I_{\max }=1.06 \pm 0.01$, and $K_{\mathrm{d}}=2.02( \pm 0.01) \times 10^{-7}$ M. For CCAP, $I_{\max }=0.99 \pm 0.02$, and $K_{\mathrm{d}}=6.7( \pm 1.1) \times 10^{-8} \mathrm{M}$.

artificial current. Below each intracellular recording is a current trace showing the amount of artificial current being injected at any given time. Because of the voltage dependence of the peptide currents, the dynamic-clamp current oscillates with the voltage swings of the cell. Moreover, because there is more inward current when the cells are depolarized, the peptide current enhances the amplitude of the oscillations and causes an increase in the number of spikes fired in each burst.

\section{Comparison of the proctolin, CCAP, and artificial rhythms}

For these experiments, we first applied proctolin $\left(10^{-6} \mathrm{M}\right)$ to the STG to elicit a control proctolin rhythm. After extensive rinsing, CCAP was applied to the STG to obtain a CCAP rhythm. While still in CCAP, we then used the dynamic clamp to inject varying amounts of the artificial peptide current into the PD and PY neurons simultaneously to see how these neurons influenced the background CCAP-elicited rhythm. We then analyzed the rhythms produced with these artificial peptide currents to see whether they had become more proctolin-like. We refer to these rhythms as the "artificial rhythm."

To assess the extent to which the CCAP rhythm became more proctolin-like, we measured the following parameters of the motor patterns: (1) the cycle frequency, (2) the burst duration of each neuron, (3) the phase of onset and termination of the burst of each neuron, (4) for single neurons (LP and IC neurons) the spike frequency within the burst, and (5) for neurons with multiple copies (PD and PY neurons) the number of spikes per burst.

In preliminary experiments we found that the artificial peptide current in the PY neuron had a pronounced effect on the burst duration of the LP neuron and that the artificial peptide current in the PD neuron influenced the cycle frequency. Therefore, the
A

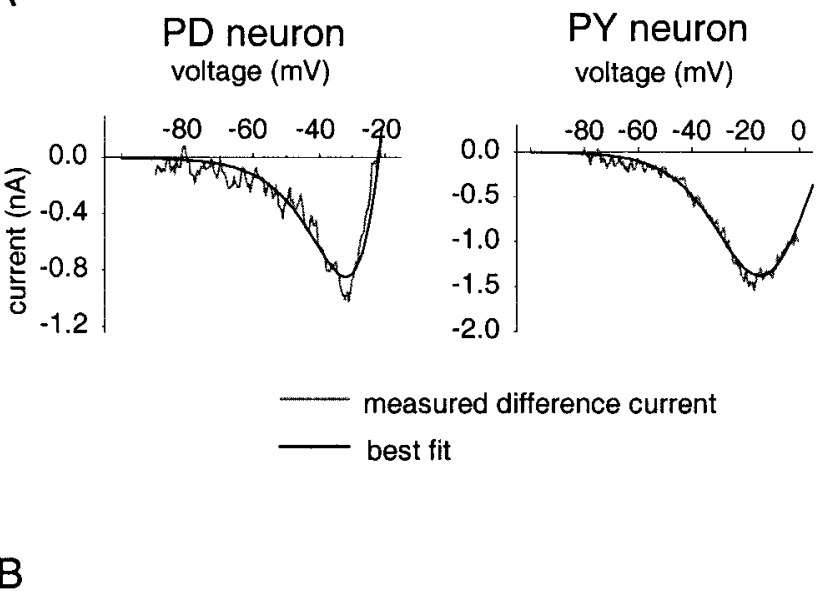

control artificial current
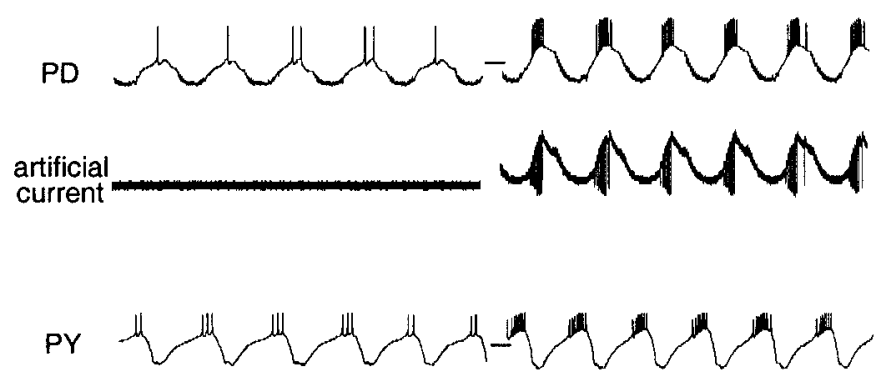

artificial current
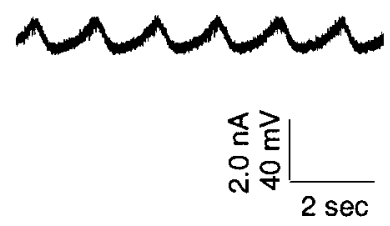

Figure 5. The artificial peptide-elicited currents for the PD and PY neurons. $A$, Proctolin currents recorded from a PD and a PY neuron and the fits that were used as the artificial peptide currents. Recordings were made using TEVC in the presence of $10 \mu \mathrm{M}$ PTX and $0.1 \mu \mathrm{M}$ TTX. Values obtained from the fits were used in the dynamic-clamp program (see Materials and Methods). B, Left, The control activity of a PD and a PY neuron. Right, How the activity of the PD and the PY neurons change with the introduction of the artificial current. Below each intracellular trace is a current trace showing the amplitude of the artificial current being injected at any given time. The horizontal line indicates $-50 \mathrm{mV}$. In these two examples the peak current values were set at $-1.8 \mathrm{nA}$ (PD neuron) and $-1.6 \mathrm{nA}$ (PY neuron).

tuning strategy we used in these experiments was first to adjust the size of the artificial peptide-activated conductance in the PY neuron until the LP burst duration was similar to what was observed in proctolin. We then adjusted the size of the artificial peptide-activated conductance in the PD neuron until the cycle frequency was similar to the observed proctolin frequency. The resulting rhythm was then compared with the proctolin rhythm across all rhythm parameters. The peak current values for the PD and PY neurons that were used in the six experiments were $-1.7 \pm 0.33 \mathrm{nA}(\mathrm{PD}$ neuron) and $-1.4 \pm 0.3 \mathrm{nA}$ (PY neuron). These values are similar to the maximal current amplitudes in the current-voltage relationships for these cells (see Fig. 5A). The mean experimental values for the peak currents elicited from pressure applications of the peptides were $-1.2 \pm 0.7 \mathrm{nA}(n=8)$ 
A.
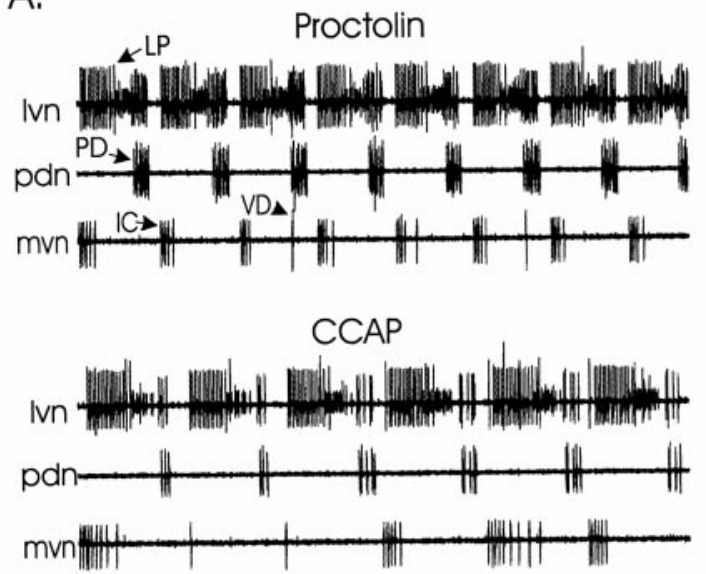

artificial rhythm

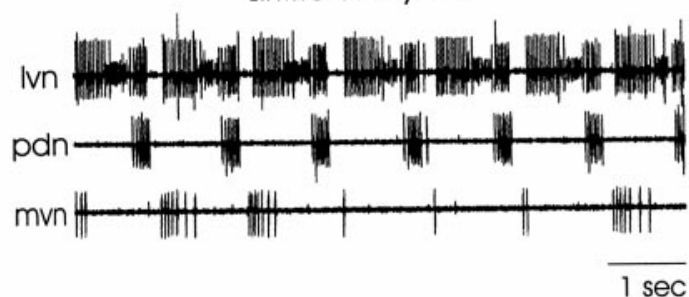

B.

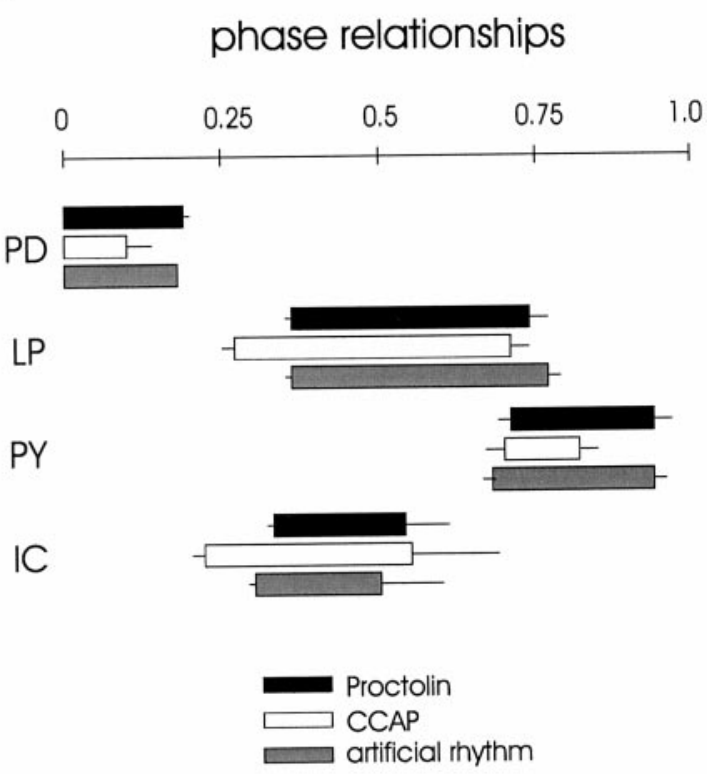

Figure 6. The proctolin-elicited, CCAP-elicited, and artificial pyloric rhythms. The artificial rhythm is the rhythm produced in the presence of CCAP while the artificial "peptide" currents were being applied to the PD and PY neurons simultaneously. A, Extracellular recordings from STG motor nerves. Spike units for the different pyloric neurons are labeled. Some of the measured values from this experiment are shown to the right. These values are averages over longer portions of the traces shown. In this experiment, the number of spikes per burst of the PY neuron was measured directly from a PY neuron. All three sets of recordings are from the same preparation. lvn, Lateral ventricular nerve; $p d n$, pyloric dilator nerve; $m v n$, medial ventricular nerve. $B$, Phase relationships of the PD, LP, PY, and IC neurons derived from the traces in $A$. Measurements are the means \pm SD. For this experiment, the peak current values for the artificial peptide currents were set at $-1.8 \mathrm{nA}$ for the PD neuron and $-1.6 \mathrm{nA}$ for the PY neuron. The CCAP concentration was $2 \times 10^{-7} \mathrm{M}$.

for the PD neuron and $-1.1 \pm 0.5 \mathrm{nA}(n=12)$ for the PY neuron. The values used for the artificial currents are a little larger than these because we were introducing the artificial current into only one of the two PD neurons and one of the PY neurons.

Figure $6 A$ shows a representative example of the proctolinelicited, CCAP-elicited, and artificial rhythms. To the right of these traces in Figure $6 A$, we plotted the measurements that are statistically different for the proctolin- and CCAP-elicited rhythms across all experiments (see below). Figure $6 B$ shows the phase relationships for the rhythms shown in Figure $6 A$.

Figure $7 A$ shows the mean values for the activity-related measurements that had statistically significant differences for the proctolin- and CCAP-elicited rhythms $(n=6)$. These values were as follows: the duration of the PD neuron $(p<0.03)$, the number of spikes per burst of the PD neuron $(p<0.001)$, the duration of the LP neuron $(p<0.001)$, the number of spikes per burst of the PY neuron $(p<0.01)$, and the overall frequency of the rhythm $(p<0.01)$. After the introduction of the artificial peptide currents into the PD and PY neurons, these values were statistically indistinguishable from those of the proctolin-elicited rhythm.

The phase plot of the average values for all experiments $(n=$ 6 ) is shown in Figure $7 B$. The phase measurements that were statistically different between the proctolin and CCAP rhythms were the following: the off-phase of the PD neuron $(p<0.01)$, the off-phase of the PY neuron $(p<0.01)$, the on-phase of the IC neuron $(p<0.005)$, and the off-phase of the IC neuron $(p<$ $0.05)$. With the introduction of the artificial peptide currents into the PD and PY neurons, only the differences in the off-phase of the PY neuron $(p<0.05)$ and the off-phase of the IC neuron $(p<0.01)$ remained statistically significant compared with the values for the proctolin-elicited rhythm. The values that were not statistically different between the proctolin- and CCAP-elicited rhythms were also not different in the artificial rhythm.

\section{Rhythm changes because of the individual effects of the PD and PY neurons}

The application of the peptide current to both the PD and PY neurons can change a CCAP-elicited rhythm into a proctolin-like rhythm. Which of the modifications in circuit output are a result of altered activity in each of the two neurons? To address this question, we also introduced the artificial peptide currents into the PD and PY neurons individually to determine which circuit parameters each neuron affected.

As might be expected, the introduction of the artificial current into the PD neuron $(n=6)$, in the presence of CCAP, significantly changed the activity of the PD neuron. The off-phase of the PD neuron increased from 0.12 to $0.17(p<0.05)$, the burst duration of the PD neuron increased from 0.18 to $0.24 \sec (p<$ 0.03 ), and the number of spikes per burst of the PD neuron increased from 3.1 to $7.0(p<0.001)$. The spike frequency of the LP neuron also showed a slight decrease $(26.0-25.1 \mathrm{~Hz} ; p<$ $0.05)$, and the on-phase of the PY neuron was delayed (0.59-0.67; $p<0.05)$. No other parameters changed significantly.

Artificial current applied to the PY neuron $(n=5)$, in the 
A

\section{mean activity-related measurements}

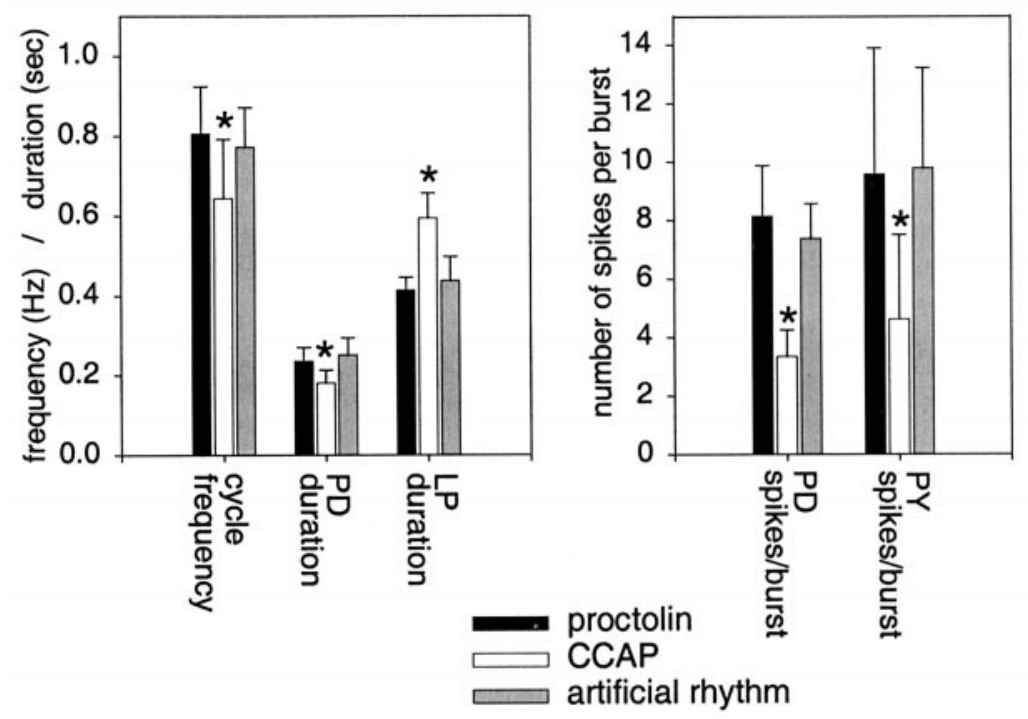

B mean phase relationships

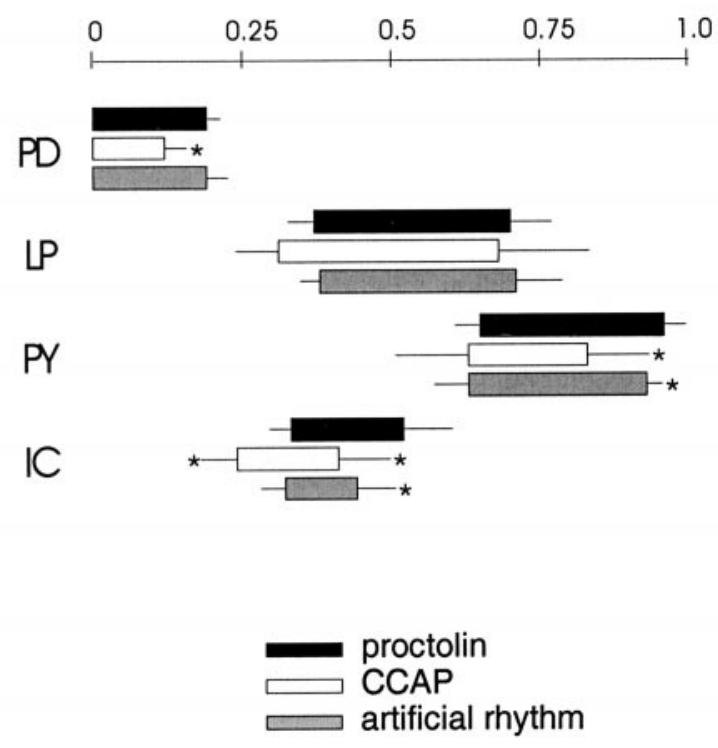

Figure 7. Comparison of proctolin-elicited, CCAP-elicited, and the artificial rhythms. $A$, Comparison of the activity-related measurements across all experiments. Only the values found to be significantly different for the CCAP rhythm, as compared with the proctolin rhythm, are shown. $B$, The phase relationships averaged across all experiments. The on-time of the PD neuron was defined as phase zero. Measurements are the means \pm SD $(n=6)$. All comparisons were made using a paired $t$ test. * denotes $p<0.05$. The concentrations of CCAP used in the experiments were the following: $1.5 \times$ $10^{-7}, 2 \times 10^{-7}, 3 \times 10^{-7}, 3.5 \times 10^{-7}, 5 \times 10^{-7}$, and $5 \times 10^{-7} \mathrm{M}$.

presence of CCAP, significantly altered the measured values for the duration of the LP neuron $(0.60-0.47 \mathrm{sec} ; p<0.03)$, the off-phase of the LP neuron $(0.72-0.66 ; p<0.02)$, the duration of the PY neuron $(0.42-0.57 \mathrm{sec} ; p<0.05)$, and the number of spikes per burst of the PY neuron $(8.3-14.8 ; p<0.01)$.

\section{The VD neuron was only weakly affected by proctolin in ongoing rhythms}

Although the isolated VD neuron responds to proctolin, the VD neuron appeared to be affected only weakly by it during ongoing rhythms (data not shown). In 12 of 13 preparations, the VD neuron was silent under control conditions. With the addition of proctolin, the VD neuron remained silent in six of these preparations and started firing weakly (one to two spikes per cycle) in the other six. In the preparation in which the VD neuron was active under control conditions, the spiking in the VD neuron only increased from one to two spikes per burst.

\section{DISCUSSION}

\section{Convergence, divergence, and redundancy}

Why do nervous systems use a vast array of neuropeptides and amines to modulate the neural circuits that control behavior? The simplest assumption might be that each substance might have a dedicated role, to modulate either a certain current or synapse. It is now abundantly clear, however, that this simple assumption is not true. In many nervous systems, multiple neuromodulatory substances converge onto the same current (Dunlap and Fischbach, 1978; Jones, 1985; Christie and North, 1988; Nicoll et al., 1990; Brezina et al., 1994a,b; Sodickson and Bean, 1998; Swensen and Marder, 2000), and many neuromodulators have actions on multiple currents (Levitan, 1988, 1994; Nicoll et al., 1990; Kiehn and Harris-Warrick, 1992b; Kloppenburg et al., 1999).

To what extent are convergent neuromodulatory actions redundant for circuit dynamics? In this paper we demonstrate that a number of neuropeptides that converge onto the same current in an individual neuron each activates a different subset of neurons within the pyloric circuit of the stomatogastric ganglion. A comparison of two of these neuropeptides, proctolin and CCAP, shows that they evoke significantly different effects on the pyloric rhythm, as a consequence of their acting on different target neurons within the pyloric network. This demonstrates clearly that physiological effects that appear to be redundant under certain assay conditions may elicit quite different actions when assayed on systems of interacting neurons.

\section{Direct and indirect effects of modulator action}

It is no surprise that neurons, which are directly excited by proctolin and CCAP when isolated, change their activity patterns when these substances are applied to the whole network. For example, the LP neuron markedly increases its firing in both substances, as noted previously (Hooper and Marder, 1984; Marder et al., 1986; Weimann et al., 1997; Swensen and Marder, 2000), and is a direct target of the peptides. However, even neurons that are not direct targets of a neuromodulator can change their activity pattern as a consequence of circuit interactions (Hooper and Marder, 1987). This point is made very clearly in the dynamic-clamp experiments in which addition of the artificial peptide current to only the PD and PY neurons results in major changes in the activity of the LP neuron.

Intuitively, the later off-phase of the PY neuron seen in the proctolin-elicited rhythms would appear to be caused directly by the proctolin current in the PY neuron. Individually introducing the artificial current into the PY neuron, however, did not have any effect on the off-phase of the PY neuron, but the introduction of the artificial current into the PD neuron did cause a small delay in the off-phase of the PY neuron, although its effect was not strong enough to be statistically significant. The simultaneous addition of the artificial current to both the PD and PY neurons 
was necessary to get a robust delay in the off-phase of the PY neuron. This suggests that the PD and PY neurons are acting synergistically to bring about some of the changes.

One of the most thorny problems in systems neuroscience is trying to evaluate the extent to which changes in circuit output are a result of specific changes in one element or component of the circuit. Dynamic-clamp experiments, such as those reported here, can provide a tool with which to assess the significance of any one portion of a circuit for the function of that circuit. For example, the pyloric frequency is higher in proctolin than in CCAP. The PD neurons, which are electrically coupled to the AB pacemaker neuron, are direct targets for proctolin but are insensitive to CCAP, suggesting that the frequency difference could be simply attributable to the difference in the peptide action directly on the PD-AB neuron pacemaker ensemble. Injecting the artificial current into the PD neuron individually, however, did not significantly affect the overall rhythm frequency, but simultaneous injections into the PD and PY neurons did significantly increase the overall frequency. This again suggests a synergistic effect of the activation of the PD and PY neurons on the rhythm frequency and illustrates that the PY neurons, which have no direct input to the pacemaker, can influence its frequency by virtue of their interactions with the LP neuron and other circuit elements.

\section{How different are the proctolin and CCAP rhythms?}

Previous work on the individual effects of proctolin and CCAP on the pyloric rhythm in $C$. borealis found that both peptides increase the burst duration and the number of action potentials per burst in the LP neuron (Marder et al., 1986; Nusbaum and Marder, 1989a,b; Weimann et al., 1997). Both peptides have statedependent effects on the pyloric frequency, generally speeding up the rhythm for slower initial pyloric frequencies $(0-0.7 \mathrm{~Hz})$ and having little or no effect for faster initial frequencies $(0.7-1.5 \mathrm{~Hz})$. Despite all these similarities, the rhythms produced by proctolin and CCAP are quantitatively different. The LP neuron is more strongly activated in CCAP than in proctolin, and the PD neuron is strongly activated only in proctolin. In this study, we normalized for the stronger activation of the LP neuron (by adjusting the concentration of CCAP) and quantitatively described the remaining differences by comparing a number of rhythm parameters. Thus, the statistical differences we report here for these two neuropeptides are an underestimate of the actual differences between the two rhythms if they were compared at the same concentrations. Nonetheless, this procedure allowed us to focus on those effects not attributable simply to the different extent of activation of the LP neuron in the two peptides.

\section{Bath application of neuromodulators}

In this study we used bath application of neuropeptides to evoke "canonical" peptide rhythms. To what extent are these likely to be the same as those rhythms induced in response to physiological release of these neuropeptides? Figure 2 shows the cell targets for each of the convergent peptides. These cell target diagrams would be those relevant to any substances released either from local neurohemal-like terminals (Kilman and Marder, 1996) or hormonally through the hemolymph (Christie et al., 1995). In these cases all of the target neurons within the STG will "see" the released modulator. All five of the peptides studied here are present hormonally, and CCAP is not found in modulatory projection neurons to the STG but acts only as a neurohormone (Dircksen and Keller, 1988; Christie et al., 1995; Johnen et al.,
1995; Dircksen, 1997). In contrast, proctolin is released from three pairs of identified modulatory projection neurons that each evoke a characteristic and different motor pattern when active (Blitz et al., 1999). Recent work argues that these different effects are not simply attributable to the different cotransmitters found in these cells but also result from differential access of proctolin to the proctolin receptors on different neurons (Wood et al., 2000).

\section{Conclusions}

It remains puzzling that the STG contains only 30 neurons, generates relatively simple motor patterns, but is modulated by at least 20 different substances (Marder and Weimann, 1992; Marder and Calabrese, 1996; Marder et al., 2001). Understanding fully the manner in which physiologically different motor patterns are encoded in convergent and divergent modulator action will require considerably more work. Nonetheless, the present results suggest that understanding the mechanisms by which modulators with apparently redundant actions influence the larger circuits found in vertebrates will require understanding, as in the STG, when modulator actions result from direct actions on specific target neurons and when changes in circuit function are an emergent property of modulator action at many sites within the circuit that together account for the final circuit output.

\section{REFERENCES}

Bidaut M (1980) Pharmacological dissection of pyloric network of the lobster stomatogastric ganglion using picrotoxin. J Neurophysiol 44:1089-1101.

Blitz DM, Christie AE, Coleman MJ, Norris BJ, Marder E, Nusbaum MP (1999) Different proctolin neurons elicit distinct motor patterns from a multifunctional neuronal network. J Neurosci 19:5449-5463.

Brezina V, Evans CG, Weiss KR (1994a) Enhancement of Ca current in the accessory radula closer muscle of Aplysia californica by neuromodulators that potentiate its contractions. J Neurosci 14:4393-4411.

Brezina V, Evans CG, Weiss KR (1994b) Activation of K current in the accessory radula closer muscle of Aplysia californica by neuromodulators that depress its contractions. J Neurosci 14:4412-4432.

Christie AE, Skiebe P, Marder E (1995) Matrix of neuromodulators in neurosecretory structures of the crab, Cancer borealis. J Exp Biol 198:2431-2439

Christie MJ, North RA (1988) Agonists at mu-opioid, M2-muscarinic and $\mathrm{GABA}_{\mathrm{B}}$-receptors increase the same potassium conductance in rat lateral parabrachial neurones. Br J Pharmacol 95:896-902.

Dircksen H (1997) Conserved crustacean cardioactive peptide: neural networks and function in arthropod evolution. In: Arthropod endocrinology-perspectives and recent advances (Coast GM, Webster SG, eds). Cambridge, U.K.: Cambridge UP.

Dircksen H, Keller R (1988) Immunocytochemical localization of CCAP, a novel crustacean cardioactive peptide, in the nervous system of the shore crab, Carcinus maenas L. Cell Tissue Res 254:347-360.

Dunlap K, Fischbach GD (1978) Neurotransmitters decrease the calcium component of sensory neurone action potentials. Nature 276:837-839.

Flamm RE, Harris-Warrick RM (1986) Aminergic modulation in lobster stomatogastric ganglion. II. Target neurons of dopamine, octopamine, and serotonin within the pyloric circuit. J Neurophysiol 55:866-881.

Golowasch J, Marder E (1992) Proctolin activates an inward current whose voltage dependence is modified by extracellular $\mathrm{Ca}^{2+}$. J Neurosci $12: 810-817$.

Harris-Warrick RM, Coniglio LM, Barazangi N, Guckenheimer J, Gueron S (1995a) Dopamine modulation of transient potassium current evokes phase shifts in a central pattern generator network. J Neurosci 15:342-358.

Harris-Warrick RM, Coniglio LM, Levini RM, Gueron S, Guckenheimer J (1995b) Dopamine modulation of two subthreshold currents produces phase shifts in activity of an identified motoneuron. J Neurophysiol 74:1404-1420.

Harris-Warrick RM, Johnson BR, Peck JH, Kloppenburg P, Ayali A, Skarbinski J (1998) Distributed effects of dopamine modulation in the crustacean pyloric network. Ann NY Acad Sci 860:155-167.

Hartline DK, Gassie DV, Sirchia CD (1987) PY cell types in the stomatogastric ganglion of Panulirus. In: The crustacean stomatogastric system (Selverston AI, Moulins M, eds), pp 75-77. Berlin: Springer.

Hooper SL, Marder E (1984) Modulation of a central pattern generator 
by two neuropeptides, proctolin and FMRFamide. Brain Res 305:186-191.

Hooper SL, Marder E (1987) Modulation of the lobster pyloric rhythm by the peptide proctolin. J Neurosci 7:2097-2112.

Johnen C, Von Gliscynski U, Dircksen H (1995) Changes in haemolymph ecdysteroid levels and CNS contents of crustacean cardioactive peptide-immunoreactivity during the moult cycle of the isopod Oniscus asellus. Netherlands J Zool 45:38-40.

Jones SW (1985) Muscarinic and peptidergic excitation of bull-frog sympathetic neurones. J Physiol (Lond) 366:63-87.

Kiehn O, Harris-Warrick RM (1992a) Serotonergic stretch receptors induce plateau properties in a crustacean motor neuron by a dualconductance mechanism. J Neurophysiol 68:485-495.

Kiehn O, Harris-Warrick RM (1992b) 5-HT modulation of hyperpolarization-activated inward current and calcium-dependent outward current in a crustacean motor neuron. J Neurophysiol 68:496-508.

Kilman VL, Marder E (1996) Ultrastructure of the stomatogastric ganglion neuropil of the crab, Cancer borealis. J Comp Neurol 374:362-375.

Kloppenburg P, Levini RM, Harris-Warrick RM (1999) Dopamine modulates two potassium currents and inhibits the intrinsic firing properties of an identified motor neuron in a central pattern generator network. J Neurophysiol 81:29-38.

Levitan IB (1988) Modulation of ion channels in neurons and other cells. Annu Rev Neurosci 11:119-136.

Levitan IB (1994) Modulation of ion channels by protein phosphorylation and dephosphorylation. Annu Rev Physiol 56:193-212.

Marder E (1987) Neurotransmitters and neuromodulators. In: The crustacean stomatogastric nervous system: a model for the study of central nervous systems (Selverston AI, Moulins M, eds), pp 263-300. New York: Springer.

Marder E, Calabrese RL (1996) Principles of rhythmic motor pattern generation. Physiol Rev 76:687-717.

Marder E, Eisen JS (1984a) Transmitter identification of pyloric neurons: electrically coupled neurons use different neurotransmitters. J Neurophysiol 51:1345-1361.

Marder E, Eisen JS (1984b) Electrically coupled pacemaker neurons respond differently to the same physiological inputs and neurotransmitters. J Neurophysiol 51:1362-1374.

Marder E, Hooper SL (1985) Neurotransmitter modulation of the stomatogastric ganglion of decapod crustaceans. In: Model neural networks and behavior (Selverston AI, ed), pp 319-337. New York: Plenum.

Marder E, Weimann JM (1992) Modulatory control of multiple task processing in the stomatogastric nervous system. In: Neurobiology of motor progamme selection (Kien J, McCrohan C, Winlow B, eds), pp 3-19. New York: Pergamon.
Marder E, Hooper SL, Siwicki KK (1986) Modulatory action and distribution of the neuropeptide proctolin in the crustacean stomatogastric nervous system. J Comp Neurol 243:454-467.

Marder E, Christie AE, Kilman VL (1995) Functional organization of cotransmission systems: lessons from small nervous systems. Invert Neurosci 1:105-112.

Marder E, Swensen AM, Blitz DM, Christie AE, Nusbaum MP (2001) Convergence and divergence of cotransmitter systems in the crab stomatogastric nervous system. In: Frontiers in crustacean neurobiology (Wiese K, ed), in press. New York: Springer.

Miller JP, Selverston A (1979) Rapid killing of single neurons by irradiation of intracellularly injected dye. Science 206:702-704.

Nicoll RA, Malenka RC, Kauer JA (1990) Functional comparison of neurotransmitter receptor subtypes in mammalian central nervous system. Physiol Rev 70:513-565.

Nusbaum MP, Marder E (1989a) A modulatory proctolin-containing neuron (MPN). I. Identification and characterization. J Neurosci 9:1591-1599.

Nusbaum MP, Marder E (1989b) A modulatory proctolin-containing neuron (MPN). II. State-dependent modulation of rhythmic motor activity. J Neurosci 9:1600-1607.

Sharp AA, O’Neil MB, Abbott LF, Marder E (1993a) The dynamic clamp: artificial conductances in biological neurons. Trends Neurosci 16:389-394.

Sharp AA, O’Neil MB, Abbott LF, Marder E (1993b) Dynamic clamp: computer-generated conductances in real neurons. J Neurophysiol 69:992-995.

Sodickson DL, Bean BP (1998) Neurotransmitter activation of inwardly rectifying potassium current in dissociated hippocampal CA3 neurons: interactions among multiple receptors. J Neurosci 18:8153-8162.

Swensen AM, Marder E (2000) Multiple peptides converge to activate the same voltage-dependent current in a central pattern-generating circuit. J Neurosci 20:6752-6759.

Weimann JM, Skiebe P, Heinzel H-G, Soto C, Kopell N, Jorge-Rivera JC, Marder E (1997) Modulation of oscillator interactions in the crab stomatogastric ganglion by crustacean cardioactive peptide. J Neurosci $17: 1748-1760$

Wood DE, Stein W, Nusbaum MP (2000) Projection neurons with shared cotransmitters elicit different motor patterns from the same neuronal circuit. J Neurosci 20:8943-8953.

Zhang B, Harris-Warrick RM (1995) Calcium-dependent plateau potentials in a crab stomatogastric ganglion motor neuron. I. Calcium current and its modulation by serotonin. J Neurophysiol 74:1929-1937.

Zhang B, Wootton JF, Harris-Warrick RM (1995) Calcium-dependent plateau potentials in a crab stomatogastric ganglion motor neuron. II. Calcium-activated slow inward current. J Neurophysiol 74:1938-1946. 